\title{
General characteristics of a multi-aged english classroom and the ways of teaching it
}

\author{
M. P. Vasylieva \\ H. S. Skovoroda Kharkiv National Pedagogical University \\ Corresponding author. E-mail: marina40680@ukr.net
}

Paper received 06.09.19; Accepted for publication 22.09.19.

\section{https://doi.org/10.31174/SEND-PP2019-203VII83-10}

\begin{abstract}
The article is devoted to giving general characteristics of a multi-aged group of learners. A multi-aged group of learners can include adolescents, adults, and senior learners. Psychological, physiological and social characteristics of each group are considered. Special attentions should be given to students' experience. Some ideas of teaching students of different age groups are provided. Special attentions should be given to students' experience.

Keywords: multi-aged group of learners, teaching, foreign languages, psychological characteristics, physiological characteristics, experience.
\end{abstract}

Introduction. It is very important to learn foreign languages nowadays. Being able to speak a foreign language provides a wide range of opportunities for work, education and travel. That is why more and more people of different ages attend language schools and courses. The members of one academic group can include teenagers, students of higher educational institutions, adults and even senior learners. In spite of the fact that a lot of research work was done dealing with particular age-groups (teaching teenagers, teaching adults, teaching senior learners), there are no research works devoted to teaching a foreign languages in a multi-aged group of learners.

The review of publications on the topic of the article. Features of foreign language learning under the conditions of higher educational establishments attracted the attention of many foreign and Ukrainian scientists. Thus, H. Artamonov, R. Bezliudnyi, Yu. Dehtiarova, I. Koval, Yu. Kolisnyk decribed peculiarities of teaching English for special purposes in non-linguistic higher educational institutions. The studies done by I. Hirenko ta $\mathrm{Yu}$. Pavlovska are devoted to the methodological issues of teaching students a foreign language. Reaseach works of $\mathrm{N}$. Hordiienko ta Yu. Laptinova deal with different aspects of teachers' work in multi-level groups of learners. Numerous works by V. Burenko, O. Hladkova, T. Hryhorieva, R. Yefymova, Ye. Kryvonosova, T. Modestova, Ye. Semenova, O. Shum are devoted to teaching English to adults. Secientits T. Polshyna, D. Starkova, V. Tylets, L. Tsviak, O. Shcherbyna study psychological peculiarities of teaching foreign languages to adults. Research works done by O. Banit, R. Presner, O. Tarnopolskyi concern organizational and pedagogical conditions of teaching English at language schools and courses. Some works of foreign scientists C. Bishop-Clark, D.F. Faust [9], Lee Ferrel, J. Lynch, R. McKinley, Mariano Sánchez [12], Michelle Schwartz [13] are devoted to general issues of teaching multi-aged groups of learners. But unfortunately, there are no scientific works dealing with teaching foreign languages to a group of students of different ages.

Materials and methods. While preparing a publication a variety of methods were used. They are: theoretical methods - analysis and synthesis, induction and deduction, comparison, analogy, used to find out about the state of the problem development and to determine the conceptual categorical apparatus; scientific provisions generali- zation and systematization as well as empirical methods questioning, testing, observation, conversation.

The aim of this article is to describe psychological, physiological, behavioral and attitudinal characteristics of a multiaged group of learners and to outline the features of foreign language teaching in such kind of group.

Results and discussions. Researchers from various fields of humanitarian knowledge - physiologists, psychologists, sociologists, researchers in the field of education have stated that a human life can be divided into three clearly defined stages, each of which has its own peculiarities.

The first stage is "immaturity". It can be divided into childhood, adolescence, youth. According to the opinions of different researchers, this stage lasts to 18-22 years.

The second stage - adulthood - lasts approximately from 20 to 65 years old (in accordance with different evaluations - from 18-24 years old to 60-70 years old). It is traditionally divided into early adulthood (approximately to 35 years), mid age (approximately to 50 years old) and late adulthood.

After a person the age of 65 a person enters a period of the "third age" [1, p. 131-135; 4, p. 12; 4, p. 53-54].

Each period of a human life has deeply studied psychological-physiological, socio-psychological, and professional features, on which the specific character of educational process organization in this period is based. The field of study which deals with teaching immature students is called pedagogy. The area of education which studies how to organize the process of teaching adults is andragogy.

Let's consider psychological, physiological, cognitive, attitudinal and behavioral characteristics of each of the above-mentioned group of learners and consider the ways of teaching a foreign language to them. A teacher should also keep in mind students' social and cultural backgrounds, their life and learning experience, preferred learning styles.

According to scientifically-grounded information, young people learn faster than adults, they can process a large amount of information in shorter periods of time [3]. Adolescents also feel comfortable about using technology, and they can easily switch from one activity to another. Young people are committed to the activities they are interested in. They have a great potential for creativity. Adolescents have already started to develop abstract 
thinking. They are better at imitating English sounds and intonation. Young people are also competitive.

Unlike older learners, most young people don't have the immediate need to use newly acquired knowledge.

The main feature of young people is their search for individual identity. Peer approval is more important for them than a teacher's attention of a [10, p. 39]. Adolescents are prone to disruptive behavior, they can't conceal their emotions, and they often bring problems from outside school to class.

Young people are usually motivated by their parents or relatives, a threat to be unsuccessful, etc. They rarely have internal motivation.

Young people don't often have a stable system of behavior and doing their work. They are bad at timemanagement and often leave doing things until the last moment.

Considering features of young people it is crucial for the teacher to be able to build rapport. A genuine interest in teens' lives helps build strong relationship with them. It is advisable to spend the first minutes of the lesson talking informally about young people's lives. It is important for the teacher to spend some time getting to know students' interests and using them while planning lessons. A teacher should also find out what types of activities teens prefer: watching videos, listening to music, making short videos, etc. Working with young people a teacher takes all the responsibility for planning and conducting lessons.

Taking into account the fact that young people easily get bored, a teacher should vary types of tasks, activities, topics, order in which they usually do things. Classes can be conducted in alternative places, too. Considering young people's desire to compete, a teacher should create more difficult tasks to keep teens engaged. There should be an element of competition, track of points and a prize system.

Let's discuss adults as foreign language learners. Recently a number of works on adult learners' characteristics have been published [5], [3], [6], [2], [7] and others.

Unlike young people, adults are usually highly motivated. They know what goal they want to achieve. Adult learners come to a classroom having a wide range of life experience: social, family, professional, basing on which they evaluate all new information. Adults' experience can serve as an important source of learning for the adults and their groupmates. Adult learners also have more learning experience. Some of them might have studied another foreign language. Adult learners want to use the knowledge they obtain as fast as possible.

Adult students are self-sufficient and independent personalities and they don't like to be dominated and ruled by other people. Unlike younger students, adult learners find it more comfortable to cooperate and collaborate with groupmates. They also prefer doing activities at their own pace.

There is no doubt that adult learners study better if they feel good physically and emotionally, have no health problems.

Adult learners have developed abstract and logical thinking. They are more disciplined than young learners and can stay concentrated for longer periods of time. Moreover, being highly motivated, adult learners are pre- pared to struggle and work hard no matter how boring the activity is.

There is a widespread opinion that people's memory worsens as they get older. It is true that a human memory deteriorates, but to a very slight extent, which doesn't prevent them from learning and obtaining new information. Moreover, there is evidence that memory capacity depends on human activity. Those people who have intellectual jobs have no problems with learning no matter how old they are [5, p.129]. Another factor to keep in mind is that adults have developed analytical abilities.

Adults are usually very busy with everyday lives. They have to combine their studies with performing professional and social duties, taking care of children and other obligations. They sometimes come to a classroom in a bad mood; have no time to do homework. To deal with the situation, a teacher's job is to create a positive atmosphere in the classroom, to cheer the learners up. Instead of giving a large amount of homework a teacher could give a few five-minute tasks which could be dome while having pauses at work, during lunch break, on a public transport, etc.

Some other problems adult learners might have include: being afraid of making a mistake, fear of losing one's authority, being afraid of looking stupid in the presence of younger learners. A teacher's task is to create a friendly atmosphere, to explain that mistakes take place in any learning process, to create situations of "success".

Another category of learners in a multi-aged English classroom is senior learners. The reasons for which senior learners attend a foreign language classroom are different. They want to be able to speak a foreign language, to read books in the original, to be able to help their grandchildren with studies, for the sake of socializing. Moreover, it has been scientifically proved that learning languages in later life helps to avoid dementia [8]. Senior learners are more disciplined and more responsible than younger students. They rarely miss classes, take an active part in a group work, and always do their homework [11].

Senior learners have some physiological and psychological peculiarities to consider. They get tired more easily. They have poorer memory than younger students. They do tasks more slowly. It is known that older learners have problems with sight and hearing. Some of senior learners can have chronic diseases. A teacher should pay attention to the light in the classroom, place seniors closer to the whiteboard, write with big letters, supplement audio-material with the script, provide more time for doing tasks. Senior learners also have a wide range of experience they would like to share.

When dealing with a multi-aged group of learners the first task a teacher needs to do is to find out students' needs. He also has to consider socio-psychological and physiological characteristics. A teacher should find an individual approach to each of his pupils. The tasks should be based on learners' experience.

A teacher's task is to create an atmosphere in which all the learners would feel comfortable.

Keeping in mind the main objective of learning a foreign language that is to acquire communicative competence, a multi-aged foreign language classroom ideally suits this purpose. A variety of students' experiences should be used to create real-life situation and to practice 
using foreign languages. Teaching materials must be relevant to their diverse life experiences and knowledge. Authentic materials are more preferable.

Conclusion. To conclude, we have to state that teaching foreign languages in a multi-aged classroom should be based on learners' psychological, physiological and sociological characteristics. A lot of attention should be paid to learners' experience. Student-oriented learning is preferred.

\section{REFERENCES}

1. Ананьев Б. Г. Человек как предмет познания. Ленинград, 1968. -324 c.

2. Григор'єва, Т. Ю. Визначення характеристик дорослого слухача як основний принцип навчання іноземних мов дорослих. Сучасні лінгвістичні студії XXI століття. Тези доповідей Всеукраӥнської науково-практичної заочної конферениіi. pp. 11-15.

3. Ефимова Р.М. Некоторые особенности обучения взрослых иностранному языку // https://www.pglu.ru/upload/iblock/f71/uch_2008_iii_00039.p df

4. Кулюткин Ю. Н. Психология обучения взрослых. Москва,

5. Шаравьёв В.А. Взрослый обучающийся краткосрочных курсов по иностранному языку: субъектная характеристика. Вестник ТГПУ. 2016. 6 (171). С. 128 - 131.

6. Щербіна О.О. Психологічні особливості навчання іноземних мов у дорослому віці. Science of the XXI century: problems and prospects of researches, 2017. № 4. C. 49-51. URL:

http://webcache.googleusercontent.com/search?q=cache:yhD dSFiH9-8J:archive.ws-conference.com/psixologichniosoblivosti-navchannya-inozemnix-mov-u-doroslomuvici/ $+\& c d=3 \& \mathrm{hl}=\mathrm{ru} \& \mathrm{ct}=\mathrm{clnk} \& \mathrm{gl}=\mathrm{ua}$ 1985. $195 \mathrm{c}$

7. Яцишин О.M. Психолого-педагогічні особливості навчання іноземної мови дорослих слухачів. Сучасні інформаиійні технології та інноваційні методики навчання у підготовичі фахівичів: методологія, теорія, досвід, проблеми. 2016. Вип. 46. С. 362-366. Режим доступу: http://nbuv.gov.ua/UJRN/Sitimn_2016_46_93.

8. BBC news. "Why the young learn more easily". BBC news, 23 November. URL: http://news.bbc.co.uk/2/hi/health/6172048.stm

9. Kieran Donaghy. How to Maximize the Language Learning of Senior Learners. URL.: https://www.teachingenglish.org.uk/article/how-maximiselanguage-learning-senior-learners

10 Harmer Jeremy. The Practice of English Language Teaching. Longman. 386 p.

11. Sánchez Mariano. Intergenerational Learning in Higher Education: Making the Case for Multigenerational Classrooms https://www.tandfonline.com/doi/abs/10.1080/03601277.201 3.844039

12. Schwartz Michelle. Teaching in Mixed-Age Classrooms. Ryerson University. URL:https://www.ryerson.ca/content/dam/lt/resources/hando uts/mixed_age_classrooms.pdf

\section{REFERENCES}

1. Ananyev B.G.A Human Being as a Subject of Cognition. Leningrad, 1968. 324 p.

2. Hryhorieva, T. Yu. Determining Adult Learners' Characteristics as a Basic Principle of Teaching Foreign Languages to Adults. Modern Linguistic Studios of the XX century. The proceedings from the All-Ukrainian scientific and practical correspondence conference. pp. 11-15.

3. Efimova R.M. Some Features of Teaching a Foreign Language to Adults. https://www.pglu.ru/upload/iblock/f71/uch_2008_iii_00039.p df

4. Kuluytkin Yu.N. The Psychology of Teaching Adults. Moscva, 1985. 195 p.
5. Sharaviev V.A. An Adult Learner of Short-term Foreign Language Courses: A Subjective Characteristic. TGPU Bulletin. 2016. 6 (171). P. $128-131$.

6. Shcherbina O.O. Psychological Characteristics of Teaching English in Adulthood. Science of the XXI century: problems and prospects of researches, 2017. № 4. P. 49-51. URL: http://webcache.googleusercontent.com/search?q=cache:yhD dSFiH9-8J:archive.ws-conference.com/psixologichniosoblivosti-navchannya-inozemnix-mov-u-doroslomuvici/ $+\& \mathrm{~cd}=3 \& \mathrm{hl}=\mathrm{ru} \& \mathrm{ct}=\mathrm{clnk} \& \mathrm{gl}=\mathrm{ua}$

7. Iatsyshyn O.M. Psychological and Pedagogical Features of Teaching Foreign Languages to Adults. Modern Information Technologies and Innovative Methods of Teaching and Training Specialists: Methodology, Theory, Experience, Problems. 2016. Issue. 46. P. 362-366. 